
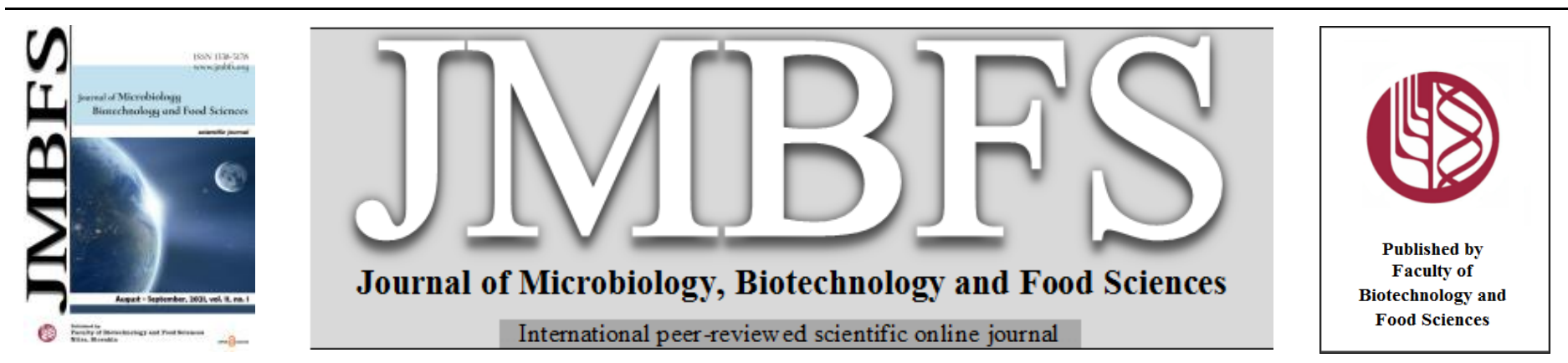

\title{
OPTIMIZING THE PRODUCTION OF PECTINASE OF ORANGE PEEL WASTE BY PENICILLIUM CHRYSOGENUM MF318506 USING RESPONSE SURFACE METHODOLOGY IN SUBMERGED FERMENTATION
}

\author{
Nehad E. Ahmed and Hassan M. Awad* \\ Address(es): Prof. Dr. Hassan M. Awad, \\ Chemistry of Natural and Microbial product Dept., Pharmaceutical and Drug Industries Research Div., National Research Centre, El-Bohouth Street, Dokki, \\ P.O.12622, Giza, Egypt.
}

*Corresponding author: awadmhassan@yahoo.com

https://doi.org/10.15414/jmbfs.3931

\section{ARTICLE INFO}

Received 4. 11. 2020

Revised 10. 2. 2021

Accepted 16. 2. 2021

Published 1. 8. 2021

Regular article

open $\odot$ access

\begin{abstract}
Pectinases find wide application in different industrial applications, e.g., textile, food, tea, paper and pulp, vegetable oil extractions, saccharification of agricultural remains, and in fermented drinks. Three fungal strains were screened for pectinase production. Results indicated that all strains are capable of producing a pectinase enzyme. Penicillium chrysogenum MF318506 showed the highest pectinase activity $(0.214 \mathrm{U} / \mathrm{ml})$ on the recommended medium at $30{ }^{\circ} \mathrm{C}$ at $150 \mathrm{rpm}$, on 6 days. Different agricultural wastes (orange peel, banana peel, potato peel, pomegranate peel, wheat bran, and rice bran) were screened as a carbon source. The maximum pectinase activity of $0.48 \mathrm{U} / \mathrm{ml}$ was obtained from Orange peel and was selected for further studies. Screening of important medium components for pectinase production by the Plackett-Burman design (PBD) showed that the maximum pectinase activity of $1.057 \mathrm{U} / \mathrm{ml}$ was achieved with $3 \%$ orange peel, $2.0 \mathrm{~g} / \mathrm{l}\left(\mathrm{NH}_{4}\right)_{2} \mathrm{SO}_{4}, 6.0 \mathrm{~g} / 1$ peptone, $6.0 \mathrm{~g} / 1 \mathrm{KH}_{2} \mathrm{PO}_{4}, 6.0 \mathrm{~g} / 1 \mathrm{~K}_{2} \mathrm{HPO}_{4}, 0.1 \mathrm{~g} / 1 \mathrm{MgSO} 4.7 \mathrm{H}_{2} \mathrm{O}, 0.5 \mathrm{~g} / 1 \mathrm{KCl}$ and $0.1 \mathrm{~g} / \mathrm{l}$ $\mathrm{FeSO}_{4}$. Finally, the Box-Behken design (BBD) which uses the response surface methodology (RSM) was applied to further optimization of the selected factors using the PBD. The maximum pectinase activity of $1.292 \mathrm{U} / \mathrm{ml}$ was observed at $2.5 \%$ orange peel and $4.5 \mathrm{~g} / \mathrm{l}$ peptone. The Statistical optimization, enhanced the pectinase production by 6.04 folds using Orange peel waste as a substrate. The pectinase produced by Penicillium chrysogenum MF318506 has potential applications in different industrial fields.
\end{abstract}

\section{INTRODUCTION}

Pectinases are a cluster of enzymes that catalyze the breakdown of pectin-holding substrates. Pectinases are classified into polygalacturonase (EC 3.2.1.15), pectinesterase (EC 3.1.1.11), pectin lyase (EC 4.2.2.10), and pectate lyase (EC 4.2.2.2) constructed on their activity. Pectinase (EC 3.2.1.15) is an enzyme that breaks down pectin in plant materials and which hydrolyzes polygalacturonic acid hooked on monoglacturonic acid by opening the glycosidic bonds and contravention ester bonds amongst carboxyl and methyl groups (Saranraj and Naidu 2014). Since pectinase is one of the greatest vital industrialized enzymes, Pectinases find a widespread request in the arena of cloth trades, nutrition productions, tea trades, paper, and soft tissue commerce, plant oil, saccharification of agricultural remains, and in fermented drinks (Chen et al. 2012); Praveen and Suneetha 2014).

Plants and microorganisms are the main enzyme production sources, but the microbial sources are considered more promising from both methodological and commercial point of view (Anisha and Girish 2014). Esmail et al. (2013) mentioned that Bacillus sp., Erwinia sp., and Pseudomonas sp. are the main creators of pectinases. As well as, pectinase produced from fungi like Aspergillus, Rhizopus, and Penicillium (Mrudula et al. 2011). More recently, pectin lyase was obtained by Penicillium $(P)$ expansum RSW_SEP1 using agricultural wastes (Atalla et al. 2019). A large number of bacterial strains, mainly Bacillus sp. (Kuvvet et al. 2017) and many filamentous fungi such as $A$. niger, A. oryzae, A. awamori, A. sojae, T. viridiae, T. virens, P. griseoroseum, and Phanerochaete chrysosporium are potential pectinase producers (Ruiz et al. (2012); Tari et al. (2007); Teixeira et al. (2011); Benoit et al. (2012); Heerd et al. (2012). Owing to the extensive uses of this enzyme, it is essential to use lowcost and willingly obtainable raw material for its construction. Employment of inexpensive carbon sources such as fruit handling waste, several lignocellulosic resources, wheat bran, soybean, sugar cane molasses, and agro-industrialized wastelands, especially from citrus fruits brans and straws, etc. can help increase enzyme productivity at a low cost (Ruiz et al. (2012); Martin et al. (2004); Martin et al. (2010); Demir and Tari (2014).
The enzymes acquired from the microbes are usually extracellular and their yield as well as the cost is extremely exaggerated by the medium components and cultivation conditions (Awad et al. 2014; Hamed et al. 2015; Atalla, et al. 2020). So, the improvement of an economically sustainable production medium needs the choice of procedure factors and their optimization approaches. The conventional method for optimal conditions of enzyme production is time waste and a daunting assignment of changing one factor at a time whereas keeping others at constant levels. An alternate and more actual method is the use of statistical analysis.

The scheming a real production medium for maximal enzyme yield is a vital procedure as the medium structure can significantly affect the enzyme activity (Ahmed et al. (2015); Djekrif- Dakhmouche et al. (2006). Plackett-Burman (PB) design has been successfully used for its efficiency in screening the essential elements in limited investigations rounds. The Plackett-Burman Experimental Design (PBED) is constructed with the idea that each element requirements its individual improper level. Moreover, it needs $4^{\mathrm{n}}$ experimentations to examine a maximal of $4^{\mathrm{n}-1}$ elements at two levels (Hibbert et al. 2012). The Box-Behnken (BB) response surface design products second-order polynomial calculations to estimate responses in assuring areas. Together with designs usage statistical analysis which can develop pectinase creation rapidly, with a significant decrease in medium charges (Tari et al. 2007). Numerous investigations have been described on numerical optimization of pectinase construction by A. niger (El Enshasy et al. (2018); Janveja and Soni (2016); Mahesh et al. (2014).

The study aimed to use the statistical designs PBD and BBD of response surface methodology (RSM) to optimize medium components for enhancing pectinase production by $P$. chrysogenum MF318506 using orange peel wastes as substrate. First, we used PBD to screen the important factors that affect pectinase production. Second, the BBD was applied to further optimization of the selected important factors using the PBD. 


\section{MATERIALS AND METHODS}

\section{Microorganism}

Three fungal strains A. terreus MN901491, A. oryzae MN894021 were isolated from red seawater at Sharm El-Shiesh province and identified by the 18S rRNA gene (Nehad et al., 2020) and P. chrysogenum MF318506 (Abd El Aty et al. 2020), were screened for pectinase production in this study. The fungal cultures were maintained on potato dextrose agar (PDA), incubated at $30^{\circ} \mathrm{C}$ for 7 days, and stored at $4^{\circ} \mathrm{C}$.

\section{Preparation of substrates}

The different agricultural wastes as orange peel, banana peel, potato peel, pomegranate peel, wheat bran, and rice bran were used as a substrate for pectinase production. The proximate analysis of these substrates was mentioned by Nehad et al. (2020). These substrates were washed, dried at $70^{\circ} \mathrm{C}$ in an oven, and powdered using a blender before use. The pest substrate was further selected to give the maximum pectinase production.

\section{Fermentation medium and pectinase production}

The medium used for pectinase production was composed of $(\mathrm{g} / \mathrm{l})$ : pectin 10 $\left(\mathrm{NH}_{4}\right)_{2} \mathrm{SO}_{4} 6 ; \mathrm{KH}_{2} \mathrm{PO}_{4}, 6 ; \mathrm{K}_{2} \mathrm{HPO}_{4} 6 ; \mathrm{MgSO}_{4} .7 \mathrm{H}_{2} \mathrm{O} 1 ;$ at $\mathrm{pH} 7.0$ (Okafor et al. (2010). Two disks $(6 \mathrm{~mm})$ in diameter from the fungal strain were cultured in 50 $\mathrm{ml}$ of fermentation medium in $250 \mathrm{ml}$ Erlenmeyer flasks and incubated at $30{ }^{\circ} \mathrm{C}$ in a rotary shaker at $150 \mathrm{rpm}$, after 6 days of fermentation, the medium was centrifuged at $4,000 \mathrm{rpm}$ for $15 \mathrm{~min}, 4^{\circ} \mathrm{C}$. The filtrate obtained was used in the enzyme assay.

\section{Enzyme assay}

Pectinase activity was carried out according to Okafor et al. (2010) who, using $1.0 \%(\mathrm{w} / \mathrm{v})$ citrus pectin as the substrate. The reaction mixture containing $1 \mathrm{ml}$ of enzyme and $1 \mathrm{ml}$ pectin (1\%), prepared in sodium acetate buffer $(0.1 \mathrm{M}, \mathrm{pH} 5.5)$ was incubated in a water bath at $50^{\circ} \mathrm{C}$ for $30 \mathrm{~min}$. After incubation, $1 \mathrm{ml}$ of DNS reagent was added and kept for $5 \mathrm{~min}$ in a boiling water bath. The absorbance was recorded at $540 \mathrm{~nm}$ using a spectrophotometer. The galacturonic acid was used as a standard. One unit $(U)$ of enzyme activity was defined as the "amount of enzyme that required to release one $\mu$ mole of galacturonic acid per minute under the standard assay conditions" (Minjares-carranco et al. 1997). Enzyme activity was calculated as:

Enzyme activity $(\mathrm{U} / \mathrm{ml})=$

Galacturonic acid released $(\mu \mathrm{M}) *$ Dilution factor / Incubation time (min)

\section{Effect of different agricultural wastes on pectinase production}

One gram of the different powdered agricultural wastes (orange peel, banana peel, potato peel, pomegranate peel, wheat bran, and rice bran) has been added as a carbon source in the fermentation medium, inoculated with $P$. chrysogenum MF318506, and incubated as the previous conditions (fermentation medium and production part). Then, pectinase activity was determined. One substrate was further selected to achieve the maximum pectinase activity.

Optimization of medium components for pectinase production by experimental designs

To determine variables that significantly affected on pectinase production by $P$. chrysogenum MF318506, the statistical software package MINITAB, Inc (version 18.1.0.0) was used, an analysis of variance (ANOVA) for the obtained results was calculated. The optimization of the important medium components was carried out in two stages.

\section{Stage one: Plackett-Burman design (PBD)}

The PBD is a two-level fractional factorial design. PBD was used to screen the important variables that significantly affect pectinase production. The total number of trials to be carried out according to Plackett-Burman is $k+1$ where $k$ is the number of variables (medium components). PBD based on the first-order model: $\mathrm{Y}=\beta \mathrm{o}+\Sigma \beta \mathrm{iXi}$, Where $\mathrm{Y}$ is the response (growth of microorganism), $\beta 0$ is the model intercept, $\beta \mathrm{i}$ is the linear coefficient, and $\mathrm{Xi}$ is the level of the independent variable. Eight independent variables (Orange peel, (NH4) ${ }_{2} \mathrm{SO}_{4}$ Peptone, $\mathrm{KH}_{2} \mathrm{PO}_{4}, \mathrm{~K}_{2} \mathrm{HPO}_{4}, \mathrm{MgSO}_{4} .7 \mathrm{H}_{2} \mathrm{O}, \mathrm{KCl}, \mathrm{FeSO}_{4}$ ) have been investigated using Plackett-Burman experimental design at two levels, low level (-1) and high level (+1), are shown in (Table 1). Eight independent variables were screened in 28 experimental runs. All experiments were carried out in duplicate and the average pectinase activity was recorded as the response. $F$ value and $P$ values and the proportion of variance $\mathrm{R} 2$ determined the model is significant at $\mathrm{P} \leq 0.05$ levels.
Table 1 Variables and their levels of the Plackett-Burman experimental design

\begin{tabular}{|c|c|c|c|}
\hline \multirow{2}{*}{ Code } & \multirow{2}{*}{ Variable } & \multicolumn{2}{|c|}{ Level } \\
\hline & & Low $(-1)$ & High $(+1)$ \\
\hline $\mathbf{A}$ & Orange peel (\%) & 1.0 & 3.0 \\
\hline B & $\left(\mathrm{NH}_{4}\right)_{2} \mathrm{SO}_{4}(\mathrm{~g} / \mathrm{l})$ & 2.0 & 6.0 \\
\hline $\mathrm{C}$ & Peptone (g/l) & 2.0 & 6.0 \\
\hline D & $\mathrm{KH}_{2} \mathrm{PO}_{4}(\mathrm{~g} / \mathrm{l})$ & 3.0 & 6.0 \\
\hline $\mathbf{E}$ & $\mathrm{K}_{2} \mathrm{HPO}_{4}(\mathrm{~g} / \mathrm{l})$ & 3.0 & 6.0 \\
\hline $\mathbf{F}$ & $\mathrm{MgSO}_{4} \cdot 7 \mathrm{H}_{2} \mathrm{O}(\mathrm{g} / \mathrm{l})$ & 0.1 & 0.5 \\
\hline G & $\mathrm{KCl}(\mathrm{g} / \mathrm{l})$ & 0.1 & 0.5 \\
\hline H & $\mathrm{FeSO}_{4}(\mathrm{~g} / \mathrm{l})$ & 0.1 & 0.2 \\
\hline
\end{tabular}

\section{Stage two: Box-Behken design (BBD)}

BBD, which uses the response surface methodology (RSM) was applied to further optimization of significant variables selected using the PBD. The variables affecting the pectinase production of the Plackett-Burman design were orange peel, peptone, and $\mathrm{KH}_{2} \mathrm{PO}_{4}$. These three factors were further studied for the optimal range in the Box-Behnken design using software package MINITAB, Inc (version 18.1.0.0). Each factor in this design was studied at three levels, the lower, center, and high levels (Table 2).

Table 2 Coded values of independent variables used in the Box-Behnken design

\begin{tabular}{lcccc}
\hline \multirow{2}{*}{ Code } & \multirow{2}{*}{ Variables } & \multicolumn{3}{c}{ Level } \\
\cline { 2 - 5 } & & -1 & 0.0 & 1 \\
\hline A & Orange peel & 2 & 2.5 & 3 \\
\hline B & Peptone & 2 & 4.0 & 6 \\
\hline $\mathrm{C}$ & $\mathrm{KH}_{2} \mathrm{PO}_{4}$ & 3 & 4.5 & 6 \\
\hline
\end{tabular}

A design of 15 experiments for 3 variables with 3 levels was performed. All experiments were carried out in duplicate and the average pectinase activity was recorded as the response.

\section{RESULTS}

\section{Screening of microorganisms for pectinase production}

Three fungal strains were screened for pectinase production. The results indicated that all strains are capable to produce pectinase. P. chrysogenum MF318506 showed the highest pectinase activity $(0.214 \mathrm{U} / \mathrm{ml})$ followed by $A$. oryzae MN894021 (0.179 U/ml) and A. terreus MN901491 (0.144 U/ml).

\section{Production of pectinase using different agriculture wastes}

Six different agricultural wastes (Orange peel, Banana peel, Potato peel, Pomegranate peel, Wheat bran, and Rice bran) were screened as a substrate for pectinase production from $P$. chrysogenum MF318506. The results in Fig. 1 revealed that orange peel gave the highest pectinase activity $(0.48 \mathrm{U} / \mathrm{ml})$ followed by pomegranate peel $(0.35 \mathrm{U} / \mathrm{ml})$. While, the Rice bran, wheat bran, and potato peel gave $(0.27,0.25,0.18 \mathrm{U} / \mathrm{ml})$ respectively.

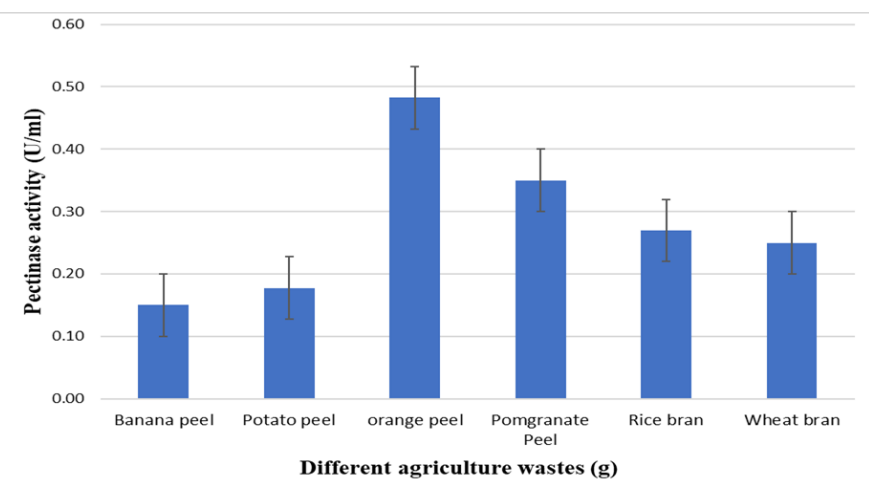

Figure 1 Production of pectinase from Penicillium chrysogenum using different agriculture wastes

Screening of essential medium constituents for pectinase production by the Plackett-Burman design

To screen the important medium components for enhancing pectinase production from $P$. chrysogenum MF318506 using orange peel as substrate Plackett-Burman 
design was used. Eight media components (Orange peel, $\left(\mathrm{NH}_{4}\right)_{2} \mathrm{SO}_{4}$, Peptone, $\mathrm{KH}_{2} \mathrm{PO}_{4}, \mathrm{~K}_{2} \mathrm{HPO}_{4}, \mathrm{MgSO}_{4} .7 \mathrm{H}_{2} \mathrm{O}, \mathrm{KCl}, \mathrm{FeSO}_{4}$ ) were investigated. Table 3 shows that the Plackett-Burman design with both the experimental and predicted response for the 28 experimental runs. The data indicated that there was a wide variation from 0.305 to $1.057 \mathrm{U} / \mathrm{ml}$ of pectinase activity in the 28 runs. This variation proposed that the optimization of the medium components had a noteworthy consequence of the pectinase activity.

Table 3 Plackett-Burman experimental design for the screening of important factors for pectinase production by $P$. chrysogenum

\begin{tabular}{lllllllllcc} 
Run & A & B & C & D & E & F & G & H & \multicolumn{2}{c}{ Pectinase activity (U/ml) } \\
\hline $\mathbf{1}$ & 3 & 6 & 2 & 3 & 6 & 0.5 & 0.5 & 0.2 & 0.521 & 0.492 \\
$\mathbf{2}$ & 3 & 6 & 6 & 3 & 3 & 0.1 & 0.5 & 0.2 & 0.697 & 0.706 \\
$\mathbf{3}$ & 1 & 6 & 2 & 3 & 3 & 0.5 & 0.1 & 0.1 & 0.373 & 0.309 \\
$\mathbf{4}$ & 3 & 6 & 6 & 3 & 3 & 0.1 & 0.1 & 0.2 & 0.675 & 0.714 \\
$\mathbf{5}$ & 3 & 6 & 6 & 3 & 3 & 0.1 & 0.5 & 0.1 & 0.719 & 0.792 \\
$\mathbf{6}$ & 3 & 6 & 2 & 6 & 6 & 0.1 & 0.1 & 0.2 & 0.641 & 0.615 \\
$\mathbf{7}$ & 1 & 2 & 2 & 6 & 3 & 0.5 & 0.5 & 0.2 & 0.316 & 0.382 \\
$\mathbf{8}$ & 1 & 2 & 6 & 6 & 3 & 0.1 & 0.5 & 0.1 & 0.807 & 0.679 \\
$\mathbf{9}$ & 1 & 2 & 6 & 3 & 3 & 0.5 & 0.1 & 0.2 & 0.486 & 0.485 \\
$\mathbf{1 0}$ & 3 & 2 & 2 & 3 & 3 & 0.5 & 0.5 & 0.1 & 0.613 & 0.652 \\
$\mathbf{1 1}$ & 1 & 6 & 2 & 6 & 3 & 0.1 & 0.1 & 0.2 & 0.429 & 0.339 \\
$\mathbf{1 2}$ & 3 & 2 & 2 & 3 & 6 & 0.1 & 0.1 & 0.2 & 0.576 & 0.592 \\
$\mathbf{1 3}$ & 1 & 6 & 2 & 3 & 6 & 0.1 & 0.5 & 0.1 & 0.305 & 0.321 \\
$\mathbf{1 4}$ & 3 & 2 & 6 & 6 & 3 & 0.5 & 0.5 & 0.2 & 0.835 & 0.850 \\
$\mathbf{1 5}$ & 1 & 2 & 2 & 3 & 6 & 0.5 & 0.5 & 0.2 & 0.450 & 0.285 \\
$\mathbf{1 6}$ & 3 & 6 & 2 & 6 & 6 & 0.5 & 0.1 & 0.1 & 0.662 & 0.679 \\
$\mathbf{1 7}$ & 3 & 2 & 2 & 6 & 3 & 0.1 & 0.1 & 0.1 & 0.753 & 0.775 \\
$\mathbf{1 8}$ & 1 & 2 & 6 & 3 & 6 & 0.1 & 0.1 & 0.1 & 0.529 & 0.590 \\
$\mathbf{1 9}$ & 1 & 6 & 6 & 3 & 6 & 0.5 & 0.5 & 0.1 & 0.474 & 0.490 \\
$\mathbf{2 0}$ & 3 & 2 & 6 & 6 & 6 & 0.5 & 0.1 & 0.1 & 0.884 & 0.941 \\
$\mathbf{2 1}$ & 1 & 6 & 6 & 6 & 6 & 0.1 & 0.5 & 0.2 & 0.584 & 0.519 \\
$\mathbf{2 2}$ & 3 & 2 & 6 & 6 & 6 & 0.1 & 0.5 & 0.1 & 1.057 & 0.955 \\
$\mathbf{2 3}$ & 1 & 2 & 2 & 3 & 3 & 0.1 & 0.1 & 0.1 & 0.460 & 0.402 \\
$\mathbf{2 4}$ & 1 & 6 & 6 & 6 & 3 & 0.5 & 0.1 & 0.2 & 0.455 & 0.508 \\
$\mathbf{2 5}$ & 1 & 2 & 2 & 6 & 6 & 0.1 & 0.5 & 0.2 & 0.369 & 0.400 \\
$\mathbf{2 6}$ & 3 & 2 & 6 & 3 & 6 & 0.5 & 0.1 & 0.2 & 0.816 & 0.592 \\
$\mathbf{2 7}$ & 1 & 6 & 6 & 6 & 6 & 0.5 & 0.1 & 0.1 & 0.566 & \\
$\mathbf{2 8}$ & 3 & 6 & 2 & 6 & 3 & 0.5 & 0.5 & 0.1 & 0.752 & \\
\hline & & & & & & & & & & Predicted \\
\hline
\end{tabular}

The outcomes showed that the maximal pectinase yield of $1.057 \mathrm{U} / \mathrm{ml}$ was detected in run 22 and achieved under optimal experimental conditions with $3 \%$ orange peel, $2.0 \mathrm{~g} / 1\left(\mathrm{NH}_{4}\right)_{2} \mathrm{SO}_{4}, 6.0 \mathrm{~g} / 1$ peptone, $6.0 \mathrm{~g} / 1 \mathrm{KH}_{2} \mathrm{PO}_{4}, 6.0 \mathrm{~g} / 1 \mathrm{~K}_{2} \mathrm{HPO}_{4}$ $0.1 \mathrm{~g} / 1 \mathrm{MgSO}_{4} .7 \mathrm{H}_{2} \mathrm{O}, 0.5 \mathrm{~g} / 1 \mathrm{KCl}$ and $0.1 \mathrm{~g} / 1 \mathrm{FeSO}_{4}$, while the lowest activity of $0.305 \mathrm{U} / \mathrm{ml}$ was achieved in run 13 .

The main effects of the examined variables on the pectinase activity were calculated and presented in the Pareto graph. The Pareto graph is a significant tool for examining all the factors and emphasis on the most important variables The Pareto chart results in Fig. 2 indicated that orange peel, peptone, and $\mathrm{KH}_{2} \mathrm{PO}_{4}$ were recorded as a strong effect on pectinase production. The relationship between the medium components and the response obtained from the 28 experiments was predicted by the first-order model regression equation:

$\mathrm{Y}($ Pectinase activity $)=$

$0.206+0.1392 \mathrm{~A}-0.01782 \mathrm{~B}+0.04757 \mathrm{C}+0.0313 \mathrm{D}-0.0009 \mathrm{E}-0.0532 \mathrm{~F}$ $0.0189 \mathrm{G}-0.860 \mathrm{H}$

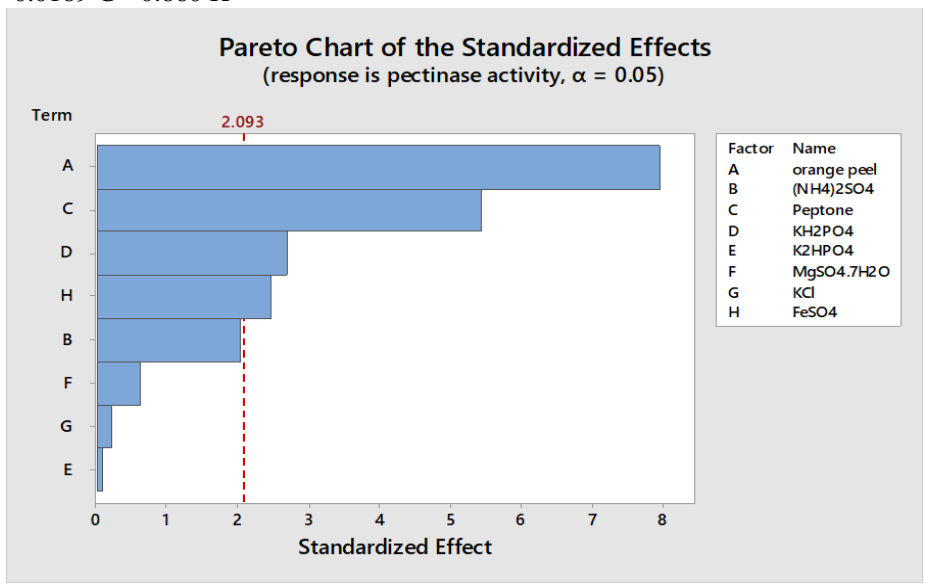

The results of pectinase activity were exposed to multiple linear regression analyses to estimate the $\mathrm{t}-$ and $\mathrm{p}$ values of each constituent. The analysis of the regression coefficients and the $t$ values of 8 variables (Table 4) revealed that values for A, C, and D had positive effects on pectinase activity, whereas B, E, F, $\mathrm{G}$, and $\mathrm{H}$ had negative effects. The significance of variables was identified as $\mathrm{A}$, $\mathrm{C}$, and D. The variables with confidence levels more than $95 \%$ was reflected as the important factors.

Table 4 Estimated effects and coefficients of the Plackett-Burman design

\begin{tabular}{lccccc}
\hline Term & Effect & Coeffi & SE Coeffi & T-Value & P-Value \\
\hline Constant & & 0.5894 & 0.0175 & 33.71 & 0.000 \\
A & 0.2784 & 0.1392 & 0.0175 & 7.96 & 0.001 \\
B & -0.0713 & -0.0356 & 0.0175 & -2.04 & 0.056 \\
C & 0.1903 & 0.0951 & 0.0175 & 5.44 & 0.024 \\
D & 0.0940 & 0.0470 & 0.0175 & 2.69 & 0.015 \\
E & -0.0026 & -0.0013 & 0.0175 & -0.07 & 0.942 \\
F & -0.0213 & -0.0106 & 0.0175 & -0.61 & 0.550 \\
G & -0.0076 & -0.0038 & 0.0175 & -0.22 & 0.831 \\
H & -0.0860 & -0.0430 & 0.0175 & -2.46 & 0.240 \\
\hline
\end{tabular}

Analysis of Variance (ANOVA) of the PBD for the pectinase production was shown in Table 5. To test the fit of the model equation can be evaluated the

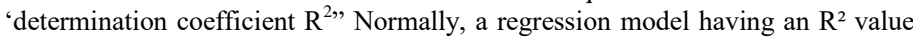
greater than 0.90 is reflected to have a very extraordinary relationship (Haaland, 1989). The $R^{2}$ value of the regression model was 0.8537 . The model $F$ value of 13.86 implies the Model is significant, the $\mathrm{p}$ values of variables A (Orange peel), $\mathrm{C}$ (Peptone), and $\mathrm{D}\left(\mathrm{KH}_{2} \mathrm{PO}_{4}\right)$ were $0.001,0.024$, and 0.015 respectively, which were considered as significantly influential for pectinase production. So, we selected the three variables: orange peel, peptone, and $\mathrm{KH}_{2} \mathrm{PO}_{4}$ as an important element for additional study to achieve the maximal enzyme activity. This showed that the PBD was a potent statistical method for selecting the significant parameters (Plackett and Burman, 1946).

Figure 2 Pareto chart showing the effect of various variables on pectinase production 
Table 5 Analysis of Variance (ANOVA) of media components by Plackett-Burman design for pectinase activity +

\begin{tabular}{|c|c|c|c|c|c|c|}
\hline Source & $\begin{array}{l}\text { Sum of } \\
\text { squares }\end{array}$ & df & $\begin{array}{c}\text { Mean } \\
\text { square }\end{array}$ & F-Value & P-Value & \\
\hline Model & 0.94893 & 8 & 0.118617 & 13.86 & 0.003 & \\
\hline orange peel & 0.54266 & 1 & 0.542657 & 63.39 & 0.001 & Significant \\
\hline$\left(\mathrm{NH}_{4}\right)_{2} \mathrm{SO}_{4}$ & 0.03557 & 1 & 0.035572 & 4.16 & 0.056 & \\
\hline Peptone & 0.25346 & 1 & 0.253461 & 29.61 & 0.024 & Significant \\
\hline $\mathrm{KH}_{2} \mathrm{PO}_{4}$ & 0.06185 & 1 & 0.061852 & 7.23 & 0.015 & Significant \\
\hline $\mathrm{K}_{2} \mathrm{HPO}_{4}$ & 0.00005 & 1 & 0.000046 & 0.01 & 0.942 & \\
\hline $\mathrm{MgSO}_{4} .7 \mathrm{H}_{2} \mathrm{O}$ & 0.00317 & 1 & 0.003172 & 0.37 & 0.550 & \\
\hline $\mathrm{KCl}$ & 0.00040 & 1 & 0.000401 & 0.05 & 0.831 & \\
\hline $\mathrm{FeSO}_{4}$ & 0.05177 & 1 & 0.051772 & 6.05 & 0.240 & \\
\hline Error & 0.16265 & 19 & 0.008561 & & & \\
\hline Total & 1.11159 & 27 & & & & \\
\hline
\end{tabular}

Optimization of medium Components for pectinase production by the BoxBehnken design

The box-Behnken design was implemented to further improve the concentrations of the most important constituents (orange peel, peptone, and $\mathrm{KH}_{2} \mathrm{PO}_{4}$ ) and the effect of their relations on pectinase activity. The BBD of variables in three levels with both the experimental and predicted response of the 15 experimental runs was shown in Table 6 . The data indicated that the highest pectinase activity ranged from 1.286 to $1.292 \mathrm{U} / \mathrm{ml}$ was achieved by the central levels of all verified 3 constituents (Table 6: Runs 4, 12, and 15).

Table 6 Box-Behnken Design (BBD) of factors in coded levels with pectinase activity as a response

\begin{tabular}{lccccc}
\hline \multirow{2}{*}{ Run } & A & B & C & \multicolumn{2}{c}{ Pectinase activity (U/ml) } \\
\cline { 5 - 6 } & & & & Experimental & Predicted \\
\hline 1 & 0 & 1 & -1 & 0.824 & 0.829 \\
3 & 0 & -1 & -1 & 0.960 & 0.965 \\
$\mathbf{4}$ & $\mathbf{0}$ & $\mathbf{0}$ & $\mathbf{0}$ & 0.838 & 0.842 \\
5 & -1 & 1 & 0 & $\mathbf{1 . 2 8 6}$ & $\mathbf{1 . 2 8 7}$ \\
6 & -1 & -1 & 0 & 0.915 & 0.904 \\
7 & 1 & 1 & 0 & 0.786 & 0.776 \\
8 & 0 & -1 & 1 & 0.995 & 1.005 \\
9 & 1 & 0 & -1 & 0.949 & 0.944 \\
10 & -1 & 0 & 1 & 0.936 & 0.921 \\
11 & 0 & 1 & 1 & 0.892 & 0.907 \\
$\mathbf{1 2}$ & $\mathbf{0}$ & $\mathbf{0}$ & $\mathbf{0}$ & 1.061 & 1.057 \\
13 & 1 & 0 & 1 & $\mathbf{1 . 2 8 3}$ & $\mathbf{1 . 2 8 7}$ \\
14 & 1 & -1 & 0 & 1.043 & 1.037 \\
15 & 0 & 0 & 0 & 0.885 & 0.896 \\
\hline
\end{tabular}

Regression analysis, which was accomplished and fitted into the subsequent the $2^{\text {ed }}$ order polynomial equation which shows the correlation between pectinase and the three variables

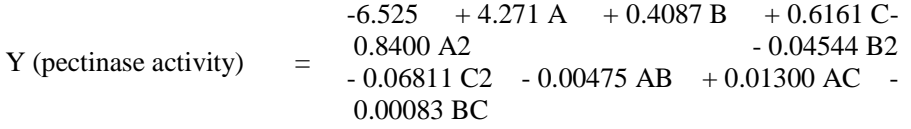

Where $\mathrm{Y}$ is the pectinase activity $(\mathrm{U} / \mathrm{ml}), \mathrm{A}, \mathrm{B}$ and $\mathrm{C}$ were the coded variables for orange peel concentration, Peptone and $\mathrm{KH}_{2} \mathrm{PO}_{4}$, respectively.

Analysis of Variance (ANOVA) of the Box-Behnken Design (BBD) for the pectinase production was shown in Table 7. From the data presented in Table 7, we found that the value of the "Predicted $\mathrm{R}^{2}$ " to be 0.9571 which is a reasonable agreement with $\mathrm{R}^{2}$ of 0.9972 and Adjusted $\mathrm{R}^{2}$ of 0.9922 . This revealed that there is a good agreement and a high correlation between values predicted by the model, and the regression model offers an exceptional clarification of the correlation amongst the independent variables and the response (pectinase production). The data presented in Table 7 indicated that the model $\mathrm{F}$ value of 199.75 suggests the Model is significant. There is only a $0.01 \%$ chance that an F-value this large could occur due to noise, The $P$ values of the model were $0.002(p<0.05)$ which showed that the model terms were significant, the values of $\mathrm{A}, \mathrm{B}, \mathrm{C}, \mathrm{A} 2, \mathrm{~B} 2$, and $\mathrm{C} 2$ were significant whereas $\mathrm{AB}, \mathrm{AC}, \mathrm{BC}$ were nonsignificant.
Table 7 Analysis of Variance (ANOVA) for response surface quadratic model of Box-Behnken Design (BBD) for the production of pectinase

\begin{tabular}{lccccc} 
Source & df & $\begin{array}{c}\text { Sum of } \\
\text { squares }\end{array}$ & $\begin{array}{c}\text { Mean } \\
\text { square }\end{array}$ & F-Value & P-Value \\
\hline Model & 9 & 0.394871 & 0.043875 & 199.75 & 0.002 \\
A- Orange peel & 1 & 0.024420 & 0.024420 & 111.18 & 0.000 \\
B-Peptone & 1 & 0.027966 & 0.027966 & 127.32 & 0.000 \\
C- $\mathrm{KH}_{2} \mathrm{PO}_{4}$ & 1 & 0.018721 & 0.018721 & 85.23 & 0.000 \\
$\mathrm{~A} 2$ & 1 & 0.162831 & 0.162831 & 741.32 & 0.000 \\
$\mathrm{~B} 2$ & 1 & 0.121968 & 0.121968 & 555.28 & 0.000 \\
$\mathrm{C} 2$ & 1 & 0.086716 & 0.086716 & 394.79 & 0.000 \\
$\mathrm{AB}$ & 1 & 0.000090 & 0.000090 & 0.41 & 0.550 \\
$\mathrm{AC}$ & 1 & 0.000380 & 0.000380 & 1.73 & 0.245 \\
$\mathrm{BC}$ & 1 & 0.000025 & 0.000025 & 0.11 & 0.750 \\
Error & 5 & 0.001098 & 0.000220 & & \\
Lack-of-Fit & 3 & 0.001056 & 0.000352 & 16.77 & 0.057 \\
Pure Error & 2 & 0.000042 & 0.000021 & & \\
Total & 14 & 0.395969 & & & \\
\hline $\mathrm{R}^{2} 0.9972 ; \mathrm{R}^{2}(\mathrm{adj})$ & $0.9922 ; \mathrm{R}^{2}($ Pred) 0.9571 & & &
\end{tabular}

The optimal concentrations of medium components yielding maximum pectinase activity has been obtained from the response surface (3D) and contour plots (2D). Response surface and contour plots (Fig. 3(A-F)) represent relations among the experimental elements (orange peel, peptone, and $\mathrm{KH}_{2} \mathrm{PO}_{4}$ ) and the response of pectinase activity. Figure (3A-3B) displays the surface and contour plots of the effect of relations among orange peel (2-3\%) and peptone (2-6 g/l) while keeping $\mathrm{KH}_{2} \mathrm{PO}_{4}$ constant at $4.5 \mathrm{~g} / \mathrm{l}$. The maximum pectinase activity of 1 . $292 \mathrm{U} / \mathrm{ml}$ was observed at $2.5 \%$ orange peel and $4 \mathrm{~g} / \mathrm{l}$ peptone. Figure (3C-3D) shows the surface and contour plots of the effect of interactions between orange peel (2-3\%) and $\mathrm{KH}_{2} \mathrm{PO}_{4}(3-6 \mathrm{~g} / \mathrm{l})$ while keeping peptone constant at $4 \mathrm{~g} / \mathrm{l}$. The outcomes presented that a higher pectinase activity was obtained at the orange peel $\left(2.5 \%\right.$ ), while $4.5 \mathrm{~g} / 1 \mathrm{~K}_{2} \mathrm{HPO}_{4}$ was proper for constructing a maximum pectinase yield.

Alternatively, the response surface and contour plot for peptone and $\mathrm{KH}_{2} \mathrm{PO}_{4}$ as shown in Fig. (3E-3F) indicated that the orange peel concentration was fixed at $2.5 \%$. As well as, the increase in both constituents progressively improved pectinase yield up to its maximum, and an additional increase caused in a reduced in pectinase yield. The last optimal peptone and $\mathrm{KH}_{2} \mathrm{PO}_{4}$ concentrations were 4 and $4.5 \mathrm{~g} / \mathrm{l}$, individually. Besides, from the model outcomes matched to our experimental runs, it can be noticed that the maximum experimental pectinase activity of $1.292 \mathrm{U} / \mathrm{ml}$ was in moral accordance with the model predicted activity of $1.287 \mathrm{U} / \mathrm{ml}$. 
$\mathrm{KH}_{2} \mathrm{PO}_{4} \quad 4.5$

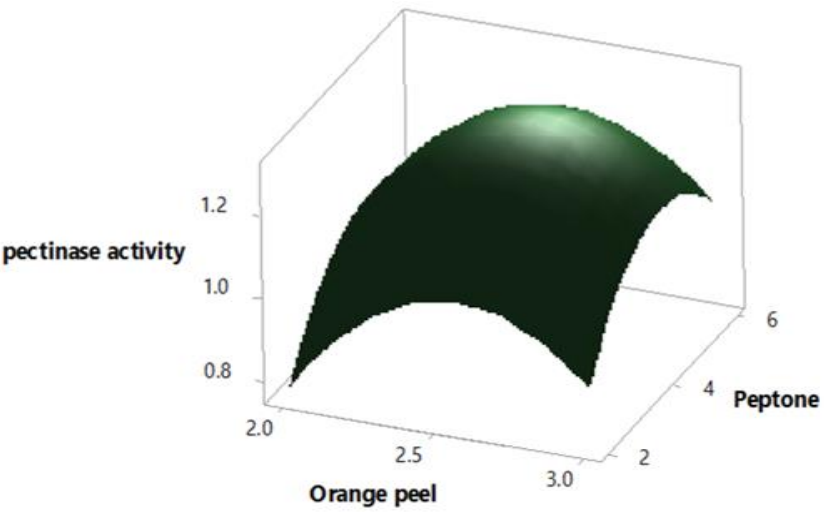

Hold value

Peptone 4

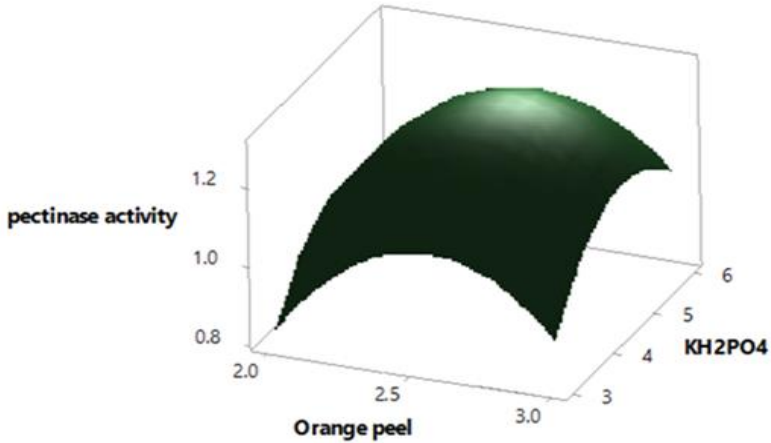

Hold value

$\mathrm{E}$

Orange peel 2.5

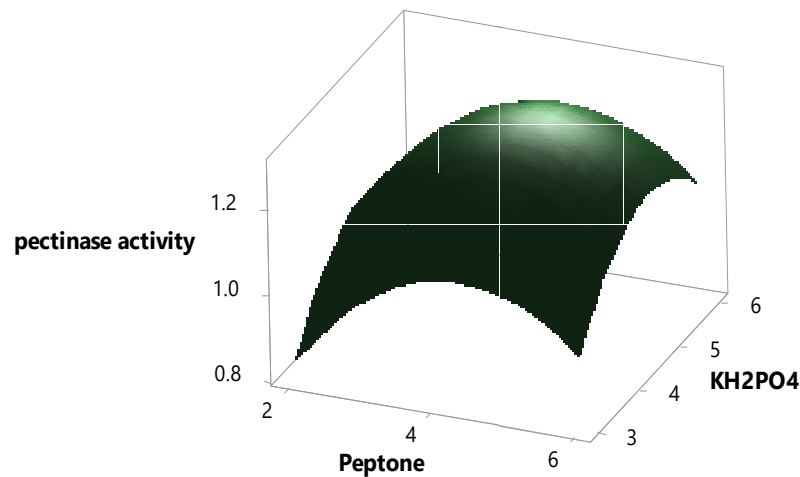

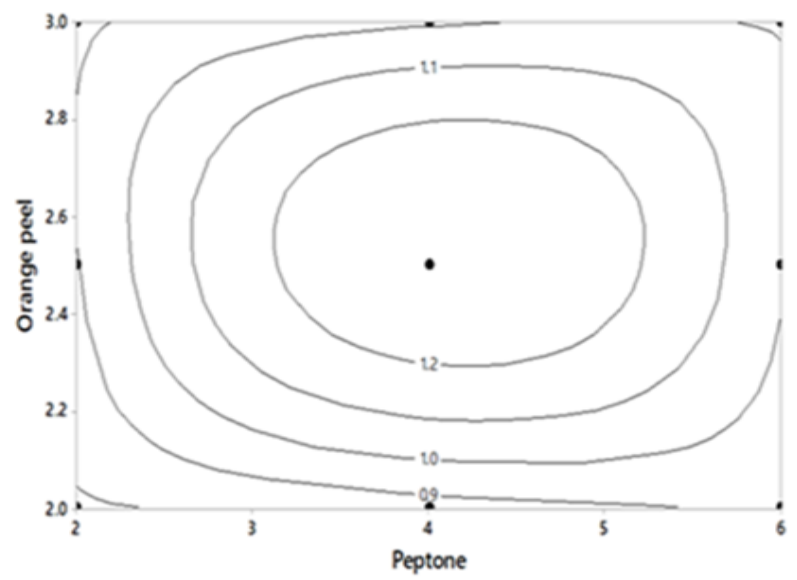

$\mathrm{D}$

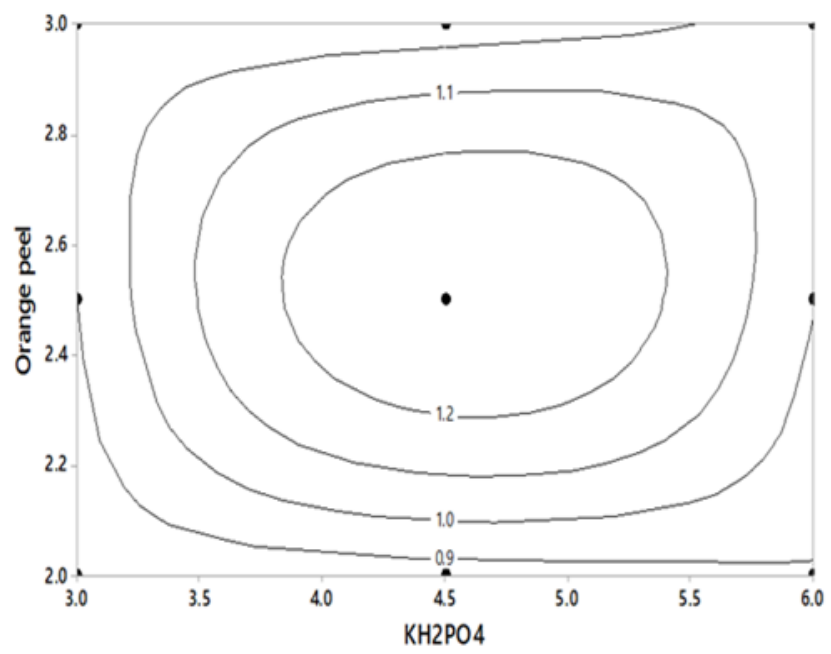

$\mathrm{F}$

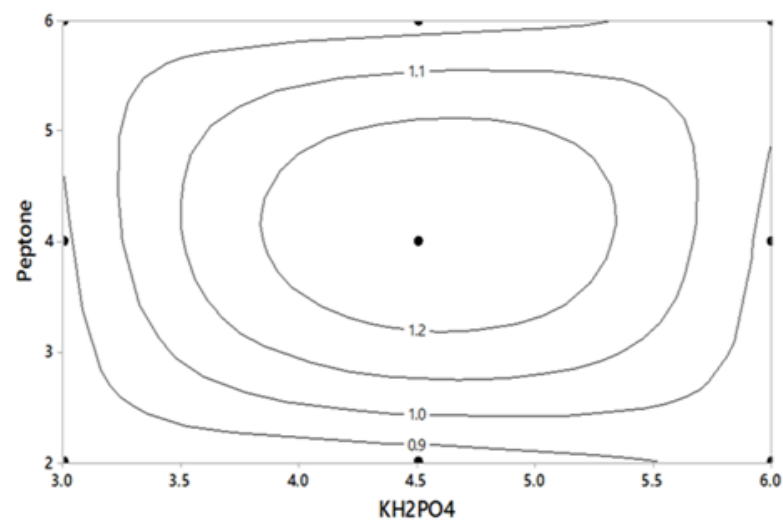

Figure 3 (A-F) Surface (A) and contour (B) plots showing the effect of interactions of orange peel concentration and peptone on pectinase activity, Surface (C) and contour (D) plots showing the effect of interactions of orange peel concentration and $\mathrm{KH}_{2} \mathrm{PO}_{4}$ on pectinase activity and Surface $(\mathrm{E})$ and contour $(\mathrm{F})$ plots showing the effect of interactions of peptone and $\mathrm{KH}_{2} \mathrm{PO}_{4}$ on pectinase activity

\section{Discussion}

Pectinase is one of the most significant industrialized enzymes, pectinases find broad, delicate in the various fields. Plants and microorganisms are the main sources of the enzyme production, however, microbial sources were considered the most promising.

A. oryzae MN894021 produced the pectinase yield of $0.214 \mathrm{U} / \mathrm{ml}$ from the first screening of different strains. The results agree with Ibarra et al. (2017) who 
mentioned that the Aspergillus, Penicillium, and Rhizopus species are universally used fungi for pectinase production. Similar results have been reported by Benzerra et al. (2012); Thangaratham Manimegalai (2014) and Abdullah et al. (2018), they indicated that A. japonicus, Penicillium sp., A. flavus, and A niger IBT-7 showed pectinolytic activity. Based on the obtained results $P$. chrysogenum was chosen in this study for further experiments.

The orange peel gave the highest pectinase activity of $0.48 \mathrm{U} / \mathrm{ml}$ (Fig. 1) Comparatively less pectinase production has been observed with banana peel waste with a yield of $0.15 \mathrm{U} / \mathrm{ml}$. These results showed that orange peel waste was the best substrate for pectinase production by $P$. chrysogenum MF318506. This is due to, the orange peel is a valuable source for pectinase production because it's rich in pectin, contains a considerable amount of valuable substances such as ash (7.39\%), fat $(1.85 \%)$, pectin $(7.0 \%)$, lignin $(6.4 \%)$, crude fiber $(7.8 \%)$, total sugar $(14.08 \%)$, reducing sugars $(10.70 \%)$ and non-reducing sugar $(3.70 \%)$, cellulose and hemicelluloses (Ahmed et al. 2016).

Also, our results agree with numerous authors who indicated that the orange peel was the best substrate for the maximal pectinase production by A. nige (Mrudulab and Anitaraj (2001); from Aspergillus sp. (Camargo et al., 2005); by $P$. oxalicum (Santos et al., 2008); from A. niger URM 4645 by Maller et al. (2011); Miciel et al. (2013), Miciel et al. (2014); from Trichoderma viridi (Irshad et al., 2014); by A. niger (Ahmed et al., 2016); from A. flavus (Thangaratham and Manimegalai, 2014).

The Plackett-Burman design data in Table 3 assigned that there was an extensive difference from 0.305 to $1.057 \mathrm{U} / \mathrm{ml}$ of pectinase activity in the 28 runs. This variance fluctuation recommended that the optimization of medium components had a significant outcome on the pectinase yield. Our data was in good agreement with those previously expressed for statistical medium optimization of pectinase activity with either fungal or bacterial microorganism (Reddy and Saritha (2016); Li et al. (2015); Yu et al. (2018). On the other hand, other parameters, e.g., $\mathrm{NH}_{4} \mathrm{Cl}, \mathrm{pH} 8.6$, and temperature have a significant effect was noticed by $\mathbf{L}$ et al. (2014) and Yu et al. (2017) who obtained pectinase by P. oxalicum PJ02 using 12 runs applying PBD and from Bacillus subtilis ZGL14, respectively. As well, the initial $\mathrm{pH}$ medium, inoculum size, and substrate concentration were indicated as a significant factor using PBD from Geotrichum candidum AA15 (Asia et al. 2019).

Analysis of Variance (ANOVA) of the PBD for the pectinase yield was revealed in Table 5. The data designated that the PBD was an influential statistical procedure for choice the essential elements (Plackett and Burman, 1946). In a previous study, El Enshasy et al. (2018) indicated that the $\mathrm{K}_{2} \mathrm{HPO}_{4}$, pectin, and $(\mathrm{NH} 4)^{2} \mathrm{SO}_{4}$ were the most significant elements affecting pectinase yield through the fractional factorial design approach. On the other hand, Zeni et al. (2014) revealed that factors, e.g., pectin, yeast extract, and potassium phosphate had significant $(\mathrm{p}<0.05)$ positive effects on the pectin lyase production cultured by $P$. brasilianum employing the $\mathrm{PBD}$

The Box-Behnken design (BBD) of variables in three levels of data indicated that the maximal pectinase yield ranged from 1.286 to $1.292 \mathrm{U} / \mathrm{ml}$ was achieved using the middle levels of all tested three constituents (Table 6: Runs 4, 12, and 15) Comparable outcomes were accounted by EI Enshasy et al. (2018) used the BoxBehnken design to further optimization of the concentrations of pectin (NH4)2SO4, and K2HPO4 in the culture medium agreeing to the three levels and exhibited that the greatest pectinase yield was obtained by the middle levels of all verified three components.

As well, the Box-Behnken design was used for the optimum conditions of pectinase production from Geotrichum candidum AA15 and the results displayed that the strain formed $0.250 \mathrm{IU} / \mathrm{ml}$ pectinase under improved environments (Asia et al. 2019). On the other hand, the highest yield of the pectinase by Rhizopus sp $\mathrm{C} 4$ uses RSM to enhance the different environmental factors (temperature, moisture, and incubation days) for a total of 20 runs via central composite design was indicated by Handa et al. (2016)

Analysis of Variance (ANOVA) of the Box-Behnken Design (BBD) for the pectinase production has appeared in Table 7 . The model of pectinase production was used to analyze the coefficient of determination (R2). The value of $\mathrm{R} 2$ comes closer to 1.0, this means that the model correlates fit (Reddy and Saritha. 2016) This is indicating the better relationship between the predicted and actual values, suggesting the goodness of the model (Li et al. 2008). A small value of R2 indicated a poor relevance of the dependent variables in the model. The mode can fit well with the actual data when R2 approaches unity (Desai et al. 2017).

From the data introduced in Table 7, the value of the "Predicted $\mathrm{R}^{2}$ " to be 0.9571 which is a reasonable agreement with $\mathrm{R}^{2}$ of 0.9972 , and Adjusted $\mathrm{R}^{2}$ of 0.9922 These results agree with El Enshasy et al. (2018) who indicated that pectinase response has an R2 value of $93.69 \%$, which designates a respectable fit of the model. The coefficient of determination (R2) value was calculated as 0.93 indicates $93.67 \%$ of the variance in response is demonstrated by this model (Asia et al. 2019). Additionally, Ajayi et al. (2018) studied that the RSM used to optimize the parameters and the central composite design with a total of 30 experiments was successful in the pectinase production process by A. niger with a correlation coefficient (R2) of 0.901

On the other hand, Handa et al. (2016) indicated that the variability in controlled response values by the experimental variables and their relations were estimated by $\mathrm{R} 2$, the predicted $\mathrm{R} 2$ value of 0.9545 by the model in a nearby contract with an actual R2 value 0.9883 disguised that the fitted linear, an interaction, and quadratic terms could elucidate $98.83 \%$ of the variation, viewing an acceptable demonstration of the process model.

The information introduced in Table 7 demonstrated that the model $\mathrm{F}$ value of 199.75, infers the Model is significant. Likewise, the achieved results are in agreement with those stated by Tari et al. (2007) where they indicated that the pvalue reveals the correlation amongst the variables, and the response variable, $p$ value lower than 0.05 , shows that the practical model is significant. The model $\mathrm{F}$ value and Probability value $(\mathrm{P}$ model $>\mathrm{F})$ of 170.45 and $<0.0001$ respectively, for pectinase activity, show that the applied model is highly significant (Handa et al. (2016). Likewise, (Asia et al. 2019) reported that the significance of the model $(p<0.05)$ was determined by Analysis of variance (ANOVA) that indicated an F-value of 8.22. On the other hand, Kuvvet et al. (2019) obtained a 2-fold increase in pectinase yield from apple pomace waste using the Box-Behnken response surface methodology by Bacillus sp.

The interactions amongst the experimental factors, e.g., orange peel, peptone $\mathrm{KH}_{2} \mathrm{PO}_{4}$, and the pectinase activity as a response by Response surface and contour plots were shown in Figures (3a-f). Ajayi et al. (2018) explained that the relationship between different parameters of temperature, $\mathrm{pH}$, and substrate concentration by the second-order polynomial. The two-dimensional contour plots were applied to establish the optimal values of the variables and found there was an important enhancement in the pectinase activity form A. niger.

\section{CONCLUSIONS}

Three fungal strains were screened for pectinase activity. Among of them, $P$. chrysogenum MF318506 gave the highest pectinase yield. Six different agricultural wastes were tested as substrates for pectinase activity and the orange peel gave the maximum pectinase activity $(0.48 \mathrm{U} / \mathrm{ml})$. Employing the PlackettBurman design denoted that the optimization of the medium components had a noteworthy effect on the pectinase activity. The maximal pectinase activity was achieved under optimum experimental conditions. By applying the Box-Behnken Design, the maximum pectinase activity of $1.292 \mathrm{U} / \mathrm{ml}$ was obtained at $2.5 \%$ orange peel and $4 \mathrm{~g} / \mathrm{l}$ peptone. The obtained results indicated that the statistical optimization, enhanced the pectinase activity from the MF318506 strain and recommend using this strain as a pectinase producer in different industrial application fields.

Acknowledgements: The authors acknowledge the National Research Centre especially Chemistry of Natural and Microbial Products Department, Pharmaceutical and Drug Industries Research Division for their supportive and assurance.

\section{REFERENCES}

Abd El Aty, A. A., Mohamed, A. A., Zohair, M. M., \& Soliman. A. A. F. (2020) Statistically controlled biogenesis of silver nano-size by Penicillium chrysogenum MF318506 for biomedical application. Biocat and Agricul Biotechnol 25: 101592. https://doi.org/10.1016/j.bcab.2020.101592

Abdullah, R., Farooq, I., Kaleem, A., Iqtedar, M., \& Iftikhar, T. (2018). Pectinase production from Aspergillus niger IBT-7 using solid-state fermentation. Bangladesh J Bot 47(3): 473-478. https://doi.org/10.3329/bjb.v47i3.38714

Ahmed, I., Zia, M. A., Hussain, M. A., Akram, Z., Naveed, M. T. \& Nowrouzi, A. (2016). Bioprocessing of citrus waste peel for induced pectinase production by Aspergillus niger, its purification and characterization. J Rad Res and Appl Sci 9:148 -154. https://doi.org/10.1016/j.jrras.2015.11.003

Ahmed, K., Ehsan, E. V. \& Ul-haq, Q. (2015). Biosynthesis, purification and characterization of commercial enzyme by Penicillium expansum link. Pak J Bot 47(4): 1521-1526

Ajayi, A. A., Salubi, A. E., Lawal, B., Onibokun, A. E., Ajayi, O. M. \& Ogunleye, T. A. (2018). Optimization of pectinase production by Aspergillus niger using central composite design. Afr J Cln Exper Microbiol 19 (4): 314-319. https://doi.org/10.4314/ajcem.v19i4.10

Anisha, S. K. \& Girish, K. (2014). Pectinolytic activity of Rhizopus sp. And Trichoderma viride. Int J Res Pure Appl Microbiol 4: 28-31.

Asia, A., Khan, M.N., Ahmed, A., Khan, S. A. \& Sohail, M. (2019) Optimization of pectinase production from Geotrichum candidum AA15 using response surface methodology. Pak J Bot 51(2): 743-750. https://doi.org/10.30848/pjb2019-2(41)

Atalla, S. M. M., EL Gamal, N. G. \& Awad, H. M. (2020). Chitinase of marine Penicillium chrysogenum MH745129: Isolation, identification, production, and characterization as a controller for citrus fruits postharvest pathogens. Jord J Biol Sci $13 ; 19-28$

Atalla, S. M. M., EL Gamal, N. G., Awad, H. M. \& Ali, N. F. (2019). Production of pectin lyase from agricultural wastes by isolated marine Penicillium expansum RSW_SEP1 as dye wool fiber. Heliyon 5 (8), e02302. https://doi.org/10.1016/j. heliyon.2019.e02302

Awad, Hassan Mohamed, Hesham Ali El-Enshasy, Siti Zulaiha Hanapi, Eman Ramadan Hamed \& Bustanur Rosidi (2014). A new chitinase-producer strain Streptomyces glauciniger WICC-A03: Isolation and identification as a biocontro 
agent for plants phytopathogenic fungi. Nat Prod Res 28 (24) p. 2273-2277. https://doi.org/10.1080/14786419.2014.939083

Benoit, I., Coutinho, P. M, Schols, H. A., Gerlach, J.P., Henrissat, B. \& de Vries R. P. (2012). Degradation of different pectinase by fungi: correlations and contrasts between the pectinolytic enzyme sets identified in genomes and the growth on pectins of different origin. BMC Genomics; 13(1):321. https://doi.org/10.1186/1471-2164-13-321

Bezerra, J. D., Santos, M.G., Svedese, V. M., Lima, D. M., Fernandes, M. J., Paiva, L. M. \& Souza-Motta, C. M. (2012). Richness of endophytic fungi isolated from Opuntia Ficus-Indica Mill. (Cactaceae) and preliminary screening for enzyme production. World J. Microbiol Biotechnol., 28(5):1989-95. https://doi.org/10.1007/s11274-011-1001-2

Camargo, L. A., Dentillo, D. B., Cardillo, L. \& Gattás, E. A. L. (2005). Utilization of orange bagasse in pectinases production by Aspergilllus sp. Alim Nutr 16(2): 153-156.

Chen, Q., Jin, Y., Zhang, G., Fang, Y., Xiao, Y. \& Zhao, H. (2012). Improving production of bioethanol from duckweeds (Landoltia punctata) by pectinase treatment. Energies 5: 3019-3032. https://doi.org/10.3390/en5083019

Dakhmouche, D., Gheribi-Aoulmi, S., Meraihi, Z. \& Bennamoun, L. (2006) Application of a statistical design to the optimization of culture medium for $\alpha$ amylase production by Aspergillus niger ATCC 16404 grown on orange waste powder. $J$ Food Process Eng 73: 190-197. https://doi.org/10.1016/j.jfoodeng.2005.01.021

Demir, H. \& Tari, C. (2014). Valorisation of wheat bran for production of polygalactouranase in SSF of Aspergillus sojae. Ind Crop Prod 54: 302-309. https://doi.org/10.1016/j.indcrop.2014.01.025

Desai, D. I. \& Iye, B. D. (2017). Utilization of corn cob waste for cellulase free xylanase production by Aspergillus niger DX-23: medium optimization and strain improvement. Waste and Biomass Valorization; 8, 103-113. https://doi.org/10.1007/s12649-016-9567-4

El Enshasy, H. A, Elsayed, A. E., Suhaimi, N., Roslinda, A.M. \& Esawy, M. (2018). Bioprocess optimization for pectinase production using Aspergillus niger in a submerged cultivation system. BMC Biotechnol 18 (71): 1-13. https://doi.org/10.1186/s12896-018-0481-7

Esmail, R., Yazaji, S. \& Balaa, B. A. I. (2013). Isolation, production and characterisation of extracellular pectin lyase from Bacillus subtilis. Adv Environ Bio 7(13):3917-24. https://doi.org/10.1016/j.bcab.2019.101306

Haaland, P. D. (1989). Separating signals from the noise in: Experimental design in biotechnology, New York, Michael Deckke, 61-83. https://doi.org/10.1201/9781003065968-4

Hamed Eman R, Hassan M Awad, Eman A Ghazi, Nadia G El-Gamal \& Heba S Shehata (2015). Trichoderma asperellum isolated from salinity soil using rice straw waste as a biocontrol agent for cowpea plant pathogens. J Appl Pharm Sci 2015, 5(1): 091-098

Handa, S., Sharma, N. \& Pathania, S. (2016). Multiple parameter optimization for maximization of pectinase production by Rhizopus sp. C4 under solid-state fermentation. Ferment 2
https://doi.org/10.3390/fermentation2020010

(2):1-

10.

https://doi.org/10.3390/fermentation2020010

Heerd, D., Yegin, S., Tari, C. \& Fernandez-Lahore, M. (2012). Pectinase enzyme-complex production by Aspergillus spp. in solid-state fermentation: a comparative study. Food Bioprod Process 90(2):102-110. https://doi.org/10.1016/i.fbp.2011.08.003

Hibbert, D. B (2012). Experimental design in chromatography: a tutorial review. J Chromatog B 910:2-13. https://doi.org/10.1016/j.jchromb.2012.01.020 Ibarra, J., Miramontes, C., Arias, A., Arriola, E., Guatemala, G. \& CoronaGonzalez, R. (2017). Production of hydrolytic enzyme by solid-state fermentation with new fungal strains using orange by-products. Rev. Mex. Ing. Quim. 16: 1931 .

Irshad, M., Anwar, Z., Mahmood, Z., Aqil, T., Mehmmod, S.\& Nawaz, H (2014). Bio-processing of agro-industrial waste orange peel for induced production of pectinase by Trichoderma viridi; its purification and characterization. Turkish J Bioch 39: (1) 9-18 https://doi.org/10.5505/tjb.2014.55707

Kuvvet, C., Uzuner, S. \& Cekmecelioglu, D. (2019). Improvement of pectinase production by co-culture of Bacillus spp. using apple pomace as a carbon source. Waste Biomass Valor 10 (5):1241-1249. https://doi.org/10.1007/s12649-0170142-4

Li, P. J, Xia, J. L., Shan, Y., Nie, Z. Y., Su, D. L, Gao, Q. R., Zhang, C. \& Ma, Y. L. (2014). Optimizing production of pectinase from orange peel by Penicillium oxalicum $\mathrm{PJ} 02$ using response surface methodology. Waste Biomass Valor https://doi.org/10.1007/s12649-014-9317-4

Li. P. J., Xia, J. L, Han, Y., Nie, Z. Y., Su, D. L, Gao, Q. R., Zhang, C., Ma, Y. L. (2015). Optimizing production of pectinase from orange peel by Penicillium oxalicum PJ02 using response surface methodology. Waste Biomass Valor 6:1322. https://doi.org/10.1007/s12649-014-9317-4

Li, X. Y., Liu, Z. Q., Chi, Z. M. (2008). Production of phytase by a marine yeast Kodamaea ohmeri BG3 in an oat medium: Optimization by response surface methodology. Biores Technol 99: 6386-6390. https://doi.org/10.1016/j.biortech.2007.11.065
Maciel, M., Ottoni, C., Santos, C., Lima, N., Moreira, K. \& Motta, C. S. (2013) Production of polygalacturonase by Aspergillus niger strains in a fixed bed reactor. Molecules 18: 1660-1671. https://doi.org/10.3390/molecules18021660 Maciel, M. H. C., Herculano, P. N., Fernandes, M. J. S., Porto, T. S., Lima, J.S., Magalhaes, O. M. C., Silva, L. R. C., Porto, A. L. F., Moreira, K. A. \& Motta, C. M..S (2014). Pectinolytic complex production by Aspergillus niger URM 4645 using yellow passion fruit peels in solid-state fermentation. Afr J Biotechnol 13 (32):3313-3322. https://doi.org/10.5897/ajb2014.13880

Mahesh, N., Vivek, R., Arunkumar, M. \& Balakumar, S. (2014). Statistical designing of enriched pectin extract medium for the enhanced production of pectinase by Aspergillus niger. Int J Pharm and Pharmaceut Sci 6: 666-672.

Maller, A., Damasio, A. R. L, Silva, T. M., Jorge, J. A., Terenzi, H. F. \& Polizeli, M. L. T. M (2011). Biotechnological potential of agro-industrial wastes as a carbon source to thermostable polygalacturonase production in Aspergillus niveus. Enzyme Res 2011:1-6. https://doi.org/10.4061/2011/289206

Martin, N., Guez, M. A. U., Sette, L.D., da Silva, R. \& Gomes, E. (2010) Pectinase production by a Brazillian thermophilic fungus Thermomucor indicae seudaticae N31 in solid and submerged fermentation. Microbiol 79: 306-313. https://doi.org/10.1134/s0026261710030057

Martin, N., de Souza, S.R., da Silva, R. \& Gomes, E. (2004). Pectinase production by fungal strains in solid-state fermentation using agro-industria bioproduct. Braz Arch Biol Technol 47(5):813-819. https://doi.org/10.1590/s1516-89132004000500018

Minjares-carranco, A., Trejo-Aguilar, B. A., Aguilar, G. \& Viniegra-Gonzaalez, G. (1997). Physiological comparison between pectinase-producing mutants of Aspergillus niger adapted either to solid-state fermentation or submerged fermentation. Enzyme and Microbial Technol 21: 25-31. https://doi.org/10.1016/s0141-0229(96)00212-8

Mrudula, S. \& Anitharaj, R. (2011). Pectinase production in solid-state fermentation by Aspergillus niger using orange peel as substrate. Global J Biotechnol Biochem 6(2):64-71.

Nehad, E. Ahmed, Aliaa, R. El Shamy, Hassan, M. Awad. (2020). Optimization and Immobilization of amylase produced by Aspergillus terreus using pomegranate peel waste. Bulletin of the National Research Centre. 44:109. https://doi.org/10.1186/s42269-020-00363-3

Okafor, U., Okochi, V., Chinedu, S., Ebuehi, O., Onygeme-okerenta, B. (2010) Pectinolytic activity of wild-type filamentous fungi fermented on agro-wastes Afr J Microbiol Res 4: 2729-2734.

Plackett, R. L. \& Burman, J. P. (1946). The design of optimum multifactoria experiments. Biometrika 37:305-325. https://doi.org/10.1093/biomet/33.4.305

Praveen, K. G., Suneetha, V. (2014). A cocktail enzyme-pectinase from fruit industrial dumpsites: a review. Res J Pharm Biol Chem Sci 5: 1252-1258.

Reddy, M., Saritha, K. V. (2016). Effects of the culture media optimization on pectinase production by Enterobacter sp. PSTB-1. J Biotech 6(2): 207 https://doi.org/10.1007/s13205-016-0502-y

Ruiz, H. A., Rodriguez-Jasso, R., Rodríguez, R., Contreras-Esquivel. J. C. \& Aguilar, C. N. (2012). Pectinase production from lemon peel pomace as support and carbon source in solid-state fermentation column-tray bioreactor. Biochem Eng $J$ 65:90-95. https://doi.org/10.1016/j.bej.2012.03.007

Santos, S. F. M., Macedo, G. R., Silva, F. L. H., Souza, R. L. A. \& Pinto, G. A S. (2008). Application of response surface methodology in the study of the production and extraction of polygalacturonase. Quim Nov 31: 1973-1978. https://doi.org/10.1590/s0100-40422008000800010

Saranraj, P., Naidu, M. A. (2014). Microbial pectinases: a review. Global J Trad Med Syst 3 (1):1-9.

Tari, C., Gögus, N. \& Tokatli, F. (2007). Optimization of biomass, pallet size and polygalacturonase production by Aspergillus sojae ATCC 20235 using response surface methodology. Enz Microb Technol 40(5):1108-16 https://doi.org/10.1016/j.enzmictec.2006.08.016

Teixeira, J. A., Gonçalves, D. B., de Queiroz, M.V. \& de Araújo, E.F. (2011) Improved pectinase production in Penicillium griseoroseum recombinant strains J Appl Microbiol 111(4):818-25. https://doi.org/10.1111/j.1365 2672.2011.05099.x

Thangaratham, T., Manimegalai, G. (2014). Optimization and production of pectinase using agro-waste by solid-state and submerged fermentation. Int J Curr Microbiol App Sci 3(9) 357-365

$\mathrm{Yu}, \quad$ P. \& Xu, C. (2018). Production optimization, purification, and characterization of a heat-tolerant acidic pectinase from Bacillus sp. ZJ1407. Inter $\quad J \quad$ Biol $\quad$ Macromol 108:972-980. https://doi.org/10.1016/j.ijbiomac.2017.11.012

Yu, P., Zhang, Y. \& Gu, D. (2017). Production optimization of a heat-tolerant alkaline pectinase from Bacillus subtilis ZGL14 and its purification and $\begin{array}{llllll}\text { characterization. } & J & \text { Bioeng } & 8(5): & 613 & -\end{array}$ https://doi.org/10.1080/21655979.2017.1292188

Zeni, J., Gomes, J., Ambroszini, E., Basso, A. P, Toniazzo, G., Valduga, E (2014). Experimental design applied to the optimization and partial characterization of pectin lyase from a newly isolated Penicillium brasilianum Braz Arch Biol Technol 57(6): 908-915. https://doi.org/10.1590/s1516$\mathbf{8 9 1 3 2 0 1 4 0 2 5 3 6}$ 